\title{
補間コントローラを用いた熱延ルーパの高さ制御*
}

\author{
西野都 $* *$. 樽崎 博司 $* *$. 北村 章 $* *$. 藤田 芳則 $* * *$. 浅田 秀樹***
}

\section{Interpolated Control of Looper Hight for Hot Strip Mills*}

\author{
Satoshi Nishino**, Hiroshi Narazaki**, Akira Kitamura**, \\ Yoshinori FuJITA ${ }^{* * *}$ and Hideki ASADA $* * *$
}

\begin{abstract}
We describe a new control system which stabilizes a looper angle variation caused by rolling disturbances. After estimating the damping coefficient of looper system, this system determines the PI controller gain based on interpolated controller scheme. Experimental results show the usefulness of the proposed method.
\end{abstract}

\section{1.はじめに}

熱延仕上げミルにおいて，各圧延スタンド間のストリッ プ張力は製品の板厚, 板幅, 板形状等の精度に及ぼす影 響が大きく, 種々の圧延外乱に対してこの張力值を一定 に制御することが要求される1)。このため各スタンド間 には,ルーパ装置が設置されていてる.

スタンド間でのストリップ張力に瞬間的な変動がある と, ルーパが動いてその変動を吸収する。しかし, 定常 状態でのストリップ張力はルーパ高さによって決まるの で，ルーパ高さを精度よく制御することは重要な課題で ある。

さて，熱延仕上げミルにおけるルーパ高さの制御では， 上流側圧延機のミルモー夕回転速度を操作量とし, 制御 法として PI 制御を用いていた (Fig. 1).

実操業ではストリップの材料特性（ヤング率）や先進 率等が圧延中に変化する。そのため, 従来の PI 制御で は, ルーパが約 $1[\mathrm{~Hz}]$ の周期でハンチングする場合があ る.このような不安定現象は, 制御対象のパラメー夕変 動をコントローラの設計で考慮しなかったことに原因が

* 原稿受付 1995 年 12 月 27 日

** (株) 神戸製鉄所 プロセス技術研究所 Process technology research laboratory, Kobe Steel Ltd.; 1-5-5 Takatsukadai, Nishi ward, Kobe City, Hyogo 651-22, JAPAN

*** (株) 神戸製鉄所 加古川製鉄所 Kakogawa works, Kobe Steel Ltd.; 1 Kanazawa-cho, Kakogawa city, Hyogo 675-01, JAPAN

Key Words: hot strip mill, looper system, interpolated controller, parameter estimation.

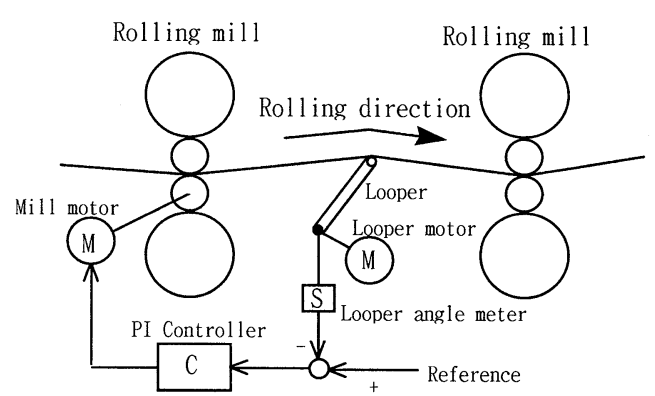

Fig. 1 Looper control system of hot strip mill

ある。

また，ルーパの制御には, PI 制御以外に非干渉制御や 多変数制御の試みがなされている2)-7)。しかし，非干涉 制御では，プロセスの特性変動によって系が不安定とな る危険性があり，また，多変数制御では調整が困難であっ たり，制御系が複雑であるという問題があった。

これらの制御方法に対して, 補間コントローラを用いた 制御方法が提案されている8)-12)。補間コントローラは, 特性変動に対して制御系を常に安定に保ち，また，補間 するコントローラをP PI コントローラとすれば，今まで の調整ノウハウが利用でき, パラメータの調整が容易で ある。

本論文では，ルーパ高さ系にパラメータ変動があって もハンチングがおこらない補間コントローラの設計方法 を提案する。 


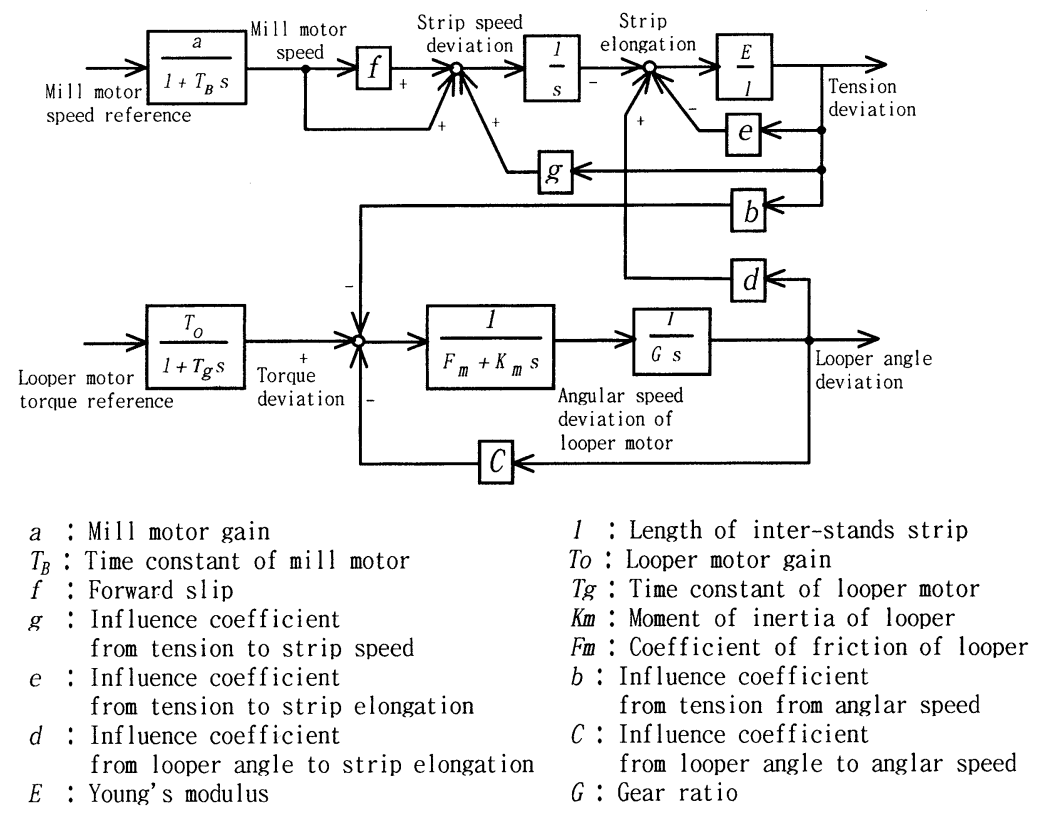

Fig. 2 Block diagram of looper dynamics

まず，2.でルーパ高さ系のモデルについて説明する． 3. では, 補間コントローラの設計手順を与え，4.で本手法の 効果をシュミレーションにより確認する．最後に，5.で実 機テストにより補間コントローラの効果を明らかにする.

\section{2. 制御対象のモデル}

ルーパ高さ系は, ミルモータへの速度指令值を入力, ル 一パ角度を出力とするシステムであり, 入出力間の制御 モデルは,

(1) ルーパとストリップの力学的な釣り合いに基づく モデル (Fig. 2 の Torque deviation から Looper angle deviation までの部分）

(2) ミルモータの速度の変動からスタンド間の張力変 動までの特性モデル (Fig. 2 の Mill motor speed から Tension deviation までの部分)

(3) ミルモータの動特性モデル (Fig. 2 の Mill motor speed reference から Mill motor speed までの 部分)

により構成される。しかし, 各モデルやモデル間の相互干 渉には, ストリップの材料特性や先進率等, 正確に把握し きれない変動パラメータが含まれており,このモデルで は突発的なハンチングをとらえきれない. そこで, 藤崎ら は, ルーパ高さ系に対し, 入出力応答よりモデリングを行 い, ルーパ高さ系 (Fig. 2 の Mill motor speed reference から Looper angle deviationまでの動特性）を「2 次遅
れ十むだ時間」で近似した ${ }^{13)}$.

ルーパ高さ系が 2 次遅れ系で近似できた理由を考える. まずミルモータの時定数は約 $0.1[\mathrm{~s}]$ であり, その応答は ルーパ力学系より十分速い. またストリップの伸びの時 定数はヤング率等より $10[\mathrm{~s}]$ 程度と考えられ, その応答は ルーパ力学系に比べて十分遅い. よって, ミルモー夕動特 性モデルとストリップ張力発生モデルの動特性の影響は 無視して問題なく, 動特性としてはルーパ力学系の 2 次 遅れで近似できる。

ここでは, 藤崎らの求めたモデル（(1) 式）を引用する.

$$
\frac{Y(s)}{U(s)}=\frac{k \omega_{n}^{2}}{s^{2}+2 \zeta \omega_{n} s+\omega_{n}^{2}} e^{-L s}
$$

ここで，Yはルーパ角度，Uはミルモー夕速度修正量, $k$ は定常ゲイン, $\omega_{n}$ は共振周波数, $\zeta$ は減衰係数, $L$ はむ だ時間である．また，ルーパ高さ系は，むだ時間，定常ゲ イン, 共振周波数はほほ一定だが減衰係数は大きく変化 することがわかっている13).

制御にはディジタルコントローラを用いるため, (1) 式 を (2) 式の後ろ向き矩形公式を用いて離散化すると (3) 式 が得られる。 


$$
\begin{aligned}
s= & \frac{1-z^{-1}}{T} \\
Y(i)= & p_{1} Y(i-1)+p_{2} Y(i-2) \\
& \quad+p_{3} U\left(i-\left\langle\frac{L}{T}\right\rangle\right) \\
p_{1}= & -2 p_{2}\left(\zeta T \omega_{n}+1\right) \\
p_{2}= & -\frac{1}{\left\{\left(T \omega_{n}\right)^{2}+2 \zeta T \omega_{n}+1\right\}} \\
p_{3}= & -k \cdot p_{2}\left(T \omega_{n}\right)^{2}
\end{aligned}
$$

ここで, $T$ はサンプリング間隔， $i$ はサンプリング時刻 〈*〉はガウス記号とする。

\section{3. 補間コントローラによる設計法}

2. で述べたようにルーパ高さ系では減衰係数が大きく 変動する. そこで, この減衰係数をオンラインで推定し, 減衰係数の変動にあわせてコントローラのゲインを変更 するという方法を考える。

\section{1 補間制御対象}

動作する環境や条件によって特性が変化するプラント の表現方法として, 代表的な動作状態におけるモデル（基 準モデル）の補間が考えられる. 制御対象の補間方法には 種々の方法が提案されている8),14)-17)が, 制御対象が伝 達関数で表現されている場合には, 基準モデルのプロパー かつ安定な有理関数による既約分解表現の線形補間8)が 適当である.

まず，制御対象が二つの基準モデルの間を変動する場 合について考える. それぞれの基準モデルを $G_{1}, G_{2}$ で あらわす. また, これらのプロパーかつ安定な有理関数 の集合 (以下, $R H^{\infty}$ と記す) 上の既約分解を

$$
G_{i}=n_{i} d_{i}^{-1}, \quad n_{i}, d_{i} \in R H^{\infty}, \quad i=1,2
$$

とする.こうすると $G_{1}, G_{2}$ の間を変動する制御対象 $G$ は,

$$
G=n d^{-1}\left\{\begin{array}{c}
n=\alpha n_{1}+(1-\alpha) n_{2} \\
d=\alpha d_{1}+(1-\alpha) d_{2} \\
0 \leq \alpha \leq 1
\end{array}\right.
$$

と表現できる(補間制御対象).

ここで，補間制御対象という考え方を項尾の注意 1 に 基づき拡大解釈し，むだ時間を含むルーパ高さ系に適用 する.

基準モデルが 2 次遅れとむだ時間であり, むだ時間が 一定であるとすると

$$
\begin{aligned}
G_{1} & =\frac{c_{1}}{s^{2}+a_{1} s+b_{1}} \cdot e^{-L s} \\
n_{1} & =\frac{c_{1}}{(s+p)^{2}} \cdot e^{-L s}, d_{1}=\frac{s^{2}+a_{1} s+b_{1}}{(s+p)^{2}} \\
G_{2} & =\frac{c_{2}}{s^{2}+a_{2} s+b_{2}} \cdot e^{-L s} \\
n_{2} & =\frac{c_{2}}{(s+p)^{2}} \cdot e^{-L s}, d_{2}=\frac{s^{2}+a_{2} s+b_{2}}{(s+p)^{2}} \\
G & =\left\{\alpha n_{1}+(1-\alpha) n_{2}\right\} \cdot\left\{\alpha d_{1}+(1-\alpha) d_{2}\right\}^{-1} \\
& =\frac{\alpha c_{1}+(1-\alpha) c_{2}}{s^{2}+\left\{\alpha a_{1}+(1-\alpha) a_{2}\right\} s+\left\{\alpha b_{1}+(1-\alpha) b_{2}\right\}} e^{-L s}
\end{aligned}
$$

となる。

熱延ルーパ高さ系では, 減衰係数が変化するため, そ れぞれの基準モデルでの減衰係数を $\zeta_{1}, \zeta_{2}$ として上記と 同様に伝達関数を求めると

$$
G=\frac{k \omega_{n}^{2}}{s^{2}+2\left\{\alpha \zeta_{1}+(1-\alpha) \zeta_{2}\right\} \omega_{n} s+\omega_{n}^{2}} e^{-L s}
$$

と表現できる。

（注意 1）参照文献 8)-12）では, 基準モデルを安定化 するコントローラとして, Youla parametrization を使用 するため $n_{i}, d_{i} \in R H^{\infty}$ としている. しかし，本論文で は，後述するように基準モデルを安定化するコントローラ として PI コントローラを使用している，そのため (10), (12) 式の $n_{1}, n_{2}$ が $R H^{\infty}$ に属する必要はない.

\section{2 補間コントローラ}

(8) 式の制御対象 $G$ とコントローラ $K$ によって構成さ れる Fig. 3 の閉ループ系の安定化問題に関して, コント ローラとして補間制御対象の $\alpha$ を利用した次式の補間コ ントローラ8)-12)を考える.

$$
K=n_{k} d_{k}^{-1}\left\{\begin{array}{c}
n_{k}=\alpha n_{k 1}+(1-\alpha) n_{k 2} \\
d_{k}=\alpha d_{k 1}+(1-\alpha) d_{k 2} \\
0 \leq \alpha \leq 1
\end{array}\right.
$$

ここで, $n_{k 1} d_{k 1}^{-1}=K_{1}, n_{k 2} d_{k 2}^{-1}=K_{2}$ はそれぞれ $G_{1}$, $G_{2}$ の安定化コントローラとする.

本論文では, コントローラの調整やメンテナンス性を 考慮して，9)，11)式の制御対象を安定化するコントロー ラ $K_{1}, K_{2}$ として次式の PI のコントローラを考える.

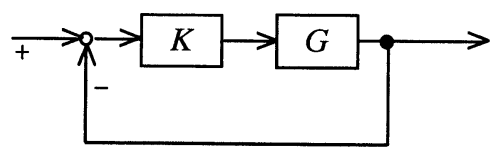

Fig. 3 Feedback control system 


$$
\begin{aligned}
K_{1} & =K p_{1}\left(1+\frac{1}{K i \cdot s}\right) \\
& =\left\{\frac{K p_{1} K i \cdot s+K p_{1}}{s+1}\right\}\left\{\frac{K i \cdot s}{s+1}\right\} \\
K_{2} & =K p_{2}\left(1+\frac{1}{K i \cdot s}\right) \\
& =\left\{\frac{K p_{2} K i \cdot s+K p_{2}}{s+1}\right\}\left\{\frac{K i \cdot s}{s+1}\right\}
\end{aligned}
$$

このとき, 補間コントローラは次式のように求まる.

$$
K=\left\{\alpha K p_{1}+(1-\alpha) K p_{2}\right\}\left(1+\frac{1}{K i \cdot s}\right)
$$

つぎに, (15) 式の制御対象と (19) 式のコントローラで構 成される Fig. 3 の閉ループ系が安定となる $K p_{1}, K p_{2}$ に ついて考察する。

実際の制御には，ディジタルコントローラを使用する ため, (15), (19) 式を (2) 式の後ろ向き矩形公式で離散化 すると次式のパルス伝達関数が得られる.ただしむだ 時間は，実機を考慮してサンプリング時間の7倍とする.

$$
\begin{aligned}
& G(z)=\frac{e_{4} z^{2}}{e_{1} z^{9}+e_{2} z^{8}+e_{3} z^{7}} \\
& e_{1}=1+2\left\{\alpha \zeta_{1}+(1-\alpha) \zeta_{2}\right\} \omega_{n} T+\omega_{n}^{2} T^{2} \\
& e_{2}=-2\left[1+\left\{\alpha \zeta_{1}+(1-\alpha) \zeta_{2}\right\} \omega_{n} T\right] \\
& e_{3}=1 \\
& e_{4}=k \omega_{n}^{2} T^{2} \\
& K(z)=\frac{f_{3} z+f_{4}}{f_{1} z+f_{2}} \\
& f_{1}=K i \\
& f_{2}=-K i \\
& f_{3}=\left\{\alpha K p_{1}+(1-\alpha) K p_{2}\right\}(K i+T) \\
& f_{4}=-\left\{\alpha K p_{1}+(1-\alpha) K p_{2}\right\} K i
\end{aligned}
$$

このとき, Fig. 3 の閉ループパルス伝達関数の分母多 項式は次式となる。

$$
\begin{aligned}
\Omega= & f_{1} e_{1} z^{8}+\left(f_{1} e_{2}+f_{2} e_{1}\right) z^{7}+\left(f_{1} e_{3}+f_{2} e_{2}\right) z^{6} \\
& +f_{2} e_{3} z^{5}+f_{3} e_{4} z+f_{4} e_{4}
\end{aligned}
$$

Fig. 3 の閉ループ系が安定となるためには，0から 1 の 任意の $\alpha$ に関して, (30) 式の $\Omega$ の根がすべて複素平面 の原点を中心とする単位円内になければならない.ここ で, $\omega_{n}, T, \zeta_{1}, \zeta_{2}, k, K i$ を定数, $K p_{1}, K p_{2}$ を設計 変数として Jury の安定判別法を用いれば, Jury 表の各 項はすべて $\alpha, K p_{1}, K p_{2}$ に関する多項式となる.ゆえ にある $K p_{1}, K p_{2}$ 対して 0 から 1 の任意の $\alpha$ に関する 多項式 $\Omega$ の安定性が判定できる.

0 から 1 の任意の $\alpha$ について, Jury の安定判別法によ る安定条件が満たされるように $K p_{1}, K p_{2}$ を調整して おけば，Fig. 3 の閉ループ系の安定性が保証できる.
0 から 1 の $\alpha$ と $\zeta_{1}$ から $\zeta_{2}$ の減衰係数は 1 対 1 対応す るので, 上述のように $K p_{1}, K p_{2}$ を決定しておけば, 減 衰係数が $\zeta_{1}$ から $\zeta_{2}$ の間の任意の值をとる場合にも (19) 式の補間コントローラにより Fig. 3 の閉ループ系の安定 性は保証される. (ルーパ高さ系の場合, $K p_{1}, K p_{2}$ は容 易に決定できる.)

複数区間の場合も同様に, 各区間内が安定となる $K p_{1}$, $K p_{2} ， \cdots$ をあらかじめオフラインで決めておけば，(19) 式の補間コントローラで制御系は安定化できる.

（注意 2）(8) 式の制御対象に (16) 式のコントローラを フィードバック結合した閉ループ系が内部安定となるた めの必要十分条件は, 参考文献 9),12)に与えられている.

\section{3 オンラインパラメータ推定}

3.2 で述べた補間コントローラを使用するには制御系 の減衰係数を知る必要がある。そのため，まず (3) 式の $p_{1}, p_{2}, p_{3}$ を $Y$ と $U$ の時系列デー夕を用いてオンライ ン推定する.その後，(4), (5) 式を連立させて $\zeta$ に関し て解いた (31) 式と推定された $p_{1}, p_{2}$ を用いて減衰係数 $\zeta$ を算出する.

$$
\zeta=\frac{p_{1}+2 p_{2}}{2 \sqrt{p_{2}\left(p_{1}+p_{2}-1\right)}}
$$

推定には逐次型最小自乗法 $((32) \sim(36)$ 式）を用いた.

$$
\begin{aligned}
& \theta=\left[\begin{array}{lll}
p_{1} & p_{2} & p_{3}
\end{array}\right]^{\mathrm{T}} \\
& \varphi(i-1)=\left[Y(i-1) Y(i-2) U\left(i-\left\langle\frac{L}{T}\right\rangle\right)\right]^{\mathrm{T}} \\
& \widehat{\theta}(i)=\widehat{\theta}(i-1)+K(i) \cdot\left(Y(i)-\varphi^{\mathrm{T}}(i-1) \cdot \widehat{\theta}(i-1)\right) \\
& K(i)=P(i-1) \cdot \varphi(i-1)\left\{\gamma+\varphi^{\mathrm{T}}(i-1) .\right. \\
& P(i-1) \cdot \varphi(i-1)\}^{-1} \\
& P(i)=\frac{\left\{I-K(i) \varphi^{\mathrm{T}}(i-1)\right\} P(i-1)}{\gamma}
\end{aligned}
$$

ただし， $\gamma$ は忘却係数である.

実機による推定結果を Fig. 4(a), (b) に示す. 図より, 約 $30[\mathrm{~s}]$ の時点からルーパが不安定化しており, 同時に減

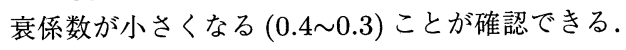

ここで, 入出力信号が定常的で, かつ振幅が小さくなる と, 推定が進まず誤差が増大するという問題がある. そこ で, (37) 式により推定結果の信頼性を評価する. 評価值 $J$

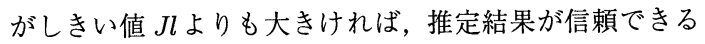
ものとし補間コントローラを用いる. 小さい場合は, 入 出力信号が安定しているので, 従来の PI 制御を用いる.

$$
\begin{aligned}
J[i]= & \lambda_{J} \cdot J[i-1] \\
& +\|Y[i]-2 Y[i-1]+Y[i-2]\|
\end{aligned}
$$

ただし， $\lambda_{J}$ は忘却係数である. 評価值 $J$ を Fig. 4(c) 


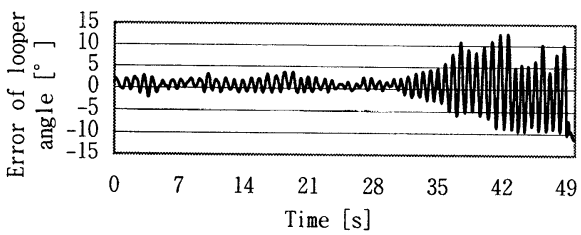

(a) Error of looper angle

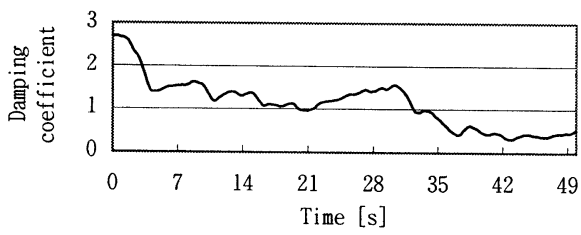

(b) Estimated damping coefficient

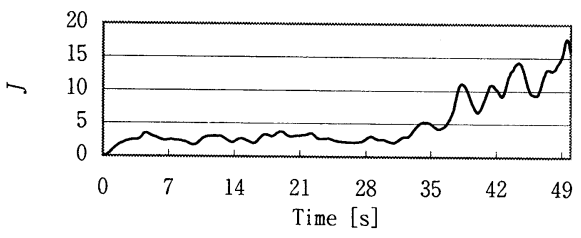

(c) Criterion $J$

Fig. 4 Paramenter estimation

に示す．図より，ルーパ角度信号が振動的になると $J$ は 増大していることが確認できる。

以上，これらを統合した制御系のブロック線図を Fig. 5 に示す.

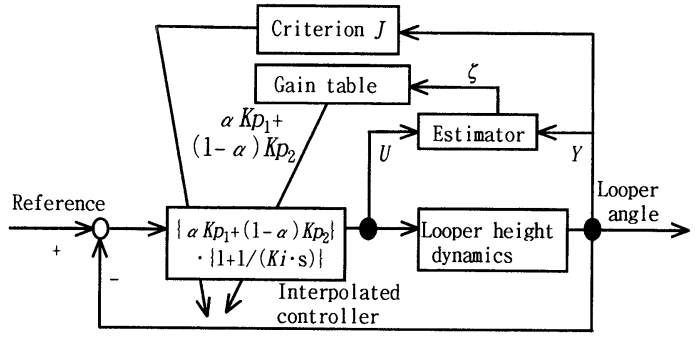

Fig. 5 Interpolated control system for looper

\section{4. シミュレーション}

補間コントローラの性能を評価するため, コンピュー タシミュレーションを行った.

ここで, 板厚 $2.3[\mathrm{~mm}]$, 板幅 $900[\mathrm{~mm}]$ の $290 \mathrm{~N}$ 鋼を想定 してパラメータを $k=5.0, \omega_{n}=7.0, L=0.28, \zeta_{1}=0.3$, $\zeta_{2}=1.4, K i=0.6, K p_{1}=0.024, K p_{2}=0.19, T=0.04$, $\gamma=0.99$ とし, 時刻 $0[\mathrm{~s}]$ から $21[\mathrm{~s}]$ にかけて減衰係数を $\zeta_{2}$ から $\zeta_{1}$ になめらかに変化させた. また, 外乱として周
波数の異なる 4 種類の正弦波を与えた。このときのルー パ角度偏差を Fig. 6(a)に, 減衰係数の変動を Fig. 6(b) に示す，比較のために，従来の PI 制御による結果と，本 論文と同一の制御対象において実機適用実績のある IMC 構造を用いたロバスト制御8)による結果を同時に示す.従 来の PI 制御では減衰係数の変動にともない, 時刻 $17[\mathrm{~s}]$ 付近から不安定化している。またロバスト制御では減衰 係数の変動が起こっても安定性は維持されているものの 本手法に比べてばらつきが大きくなる．本手法では減衰 係数が変化しても安定性が維持され, かつ, ばらつきも 減衰係数が大きいときの PI 制御と同等の性能を有する ことが確認できる.

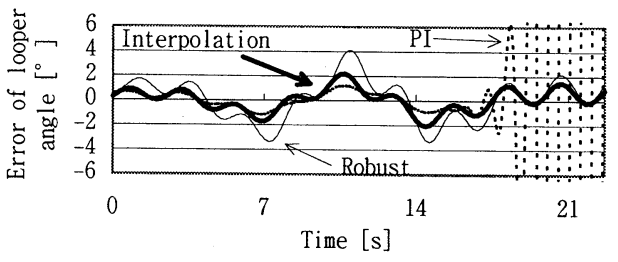

(a) Error of looper

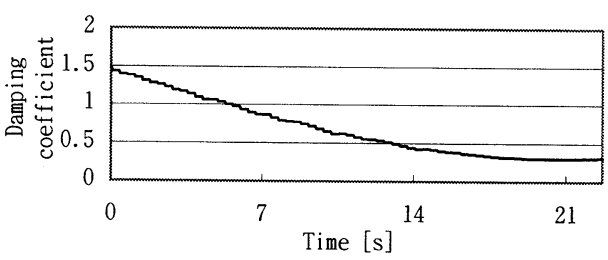

(b) Damping coefficient

Fig. 6 Simulation results

\section{5. 実機適用結果}

熱延仕上げミルのルーパ装置において本制御法のオン ラインテストを行った. ここで, $\zeta_{1}=0.3, \zeta_{2}=1.5, K p_{1}=$ $0.02, K p_{2}=0.19, K i=0.6, T=0.04, \gamma=0.99, \lambda_{J}=$ 0.95 とし, $J l$ に関しては $J l=5.5$ としたケースと $J l=4.0$ としたケースの 2 種類のテストを行った.

まず, Fig. 7 に $J l=5.5$ としたケース, Fig. 8 には $J l=4.0$ としたケースの実験結果を示す. それぞれ，(a) がルーパ角度偏差，(b) がゲインを表している.

Fig. 7 では $J l$ の值が大きいためゲインを減少させる方 向への修正のタイミングが遅くなり，ハンチングを抑制 しきれないがゲインの修正によって系を安定化できるこ とは確認できる。これに対して Fig. 8 では Jlを適正な值 に設定しているためゲインの減少方向への修正によって ハンチングを未然に制御している。このように減衰係数 の変動を監視し，ハンチングを未然に制御することがで 


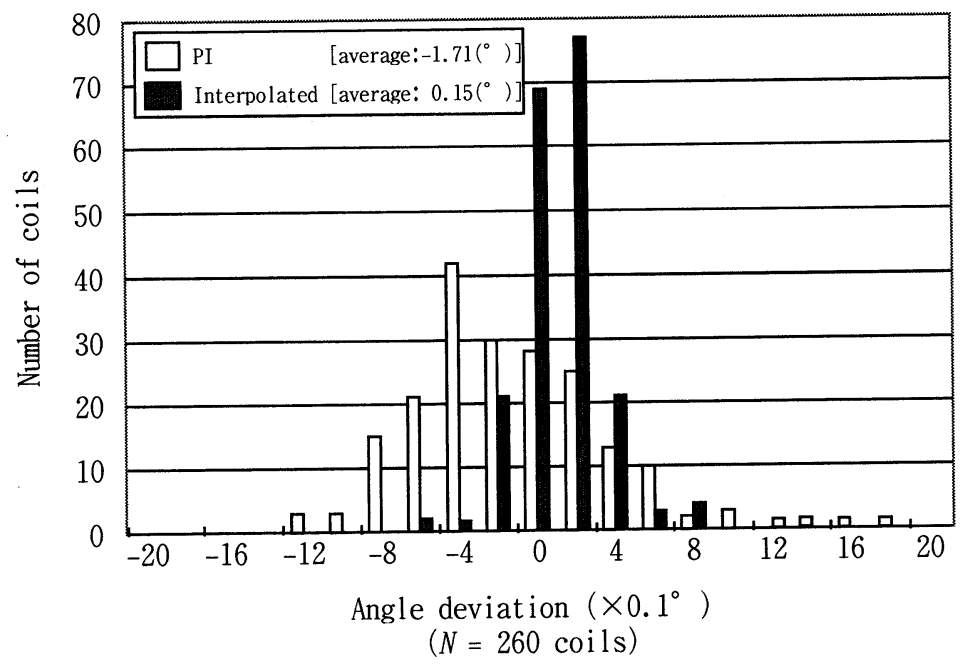

Fig. 9 Effect of interpolated control system for looper

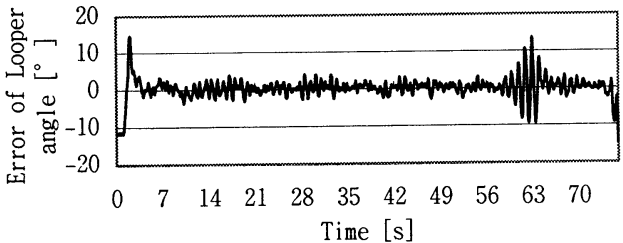

(a) Error of looper angle

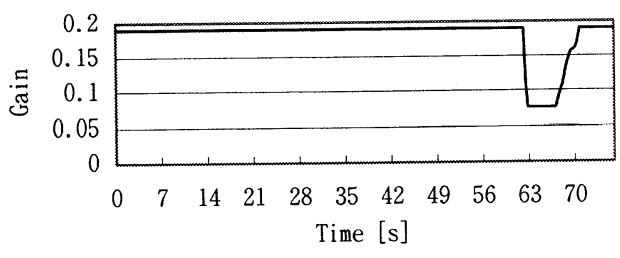

(b) Gain intervention value

Fig. 7 Test results by interpolated control $(J l=5.5)$

きれば，ハンチングによるミスロールの心配がなくなり， 評価值 $J$ がしきい值 $J l$ よりも小さい場合の従来の PI コ ントローラのゲイン（デフォルトとしているゲイン）を 高く設定することができる.

つぎに, デフォルトとしているゲインを従来の 1.5 倍 に設定し, 本手法を適用した場合の各コイルの先後端を 除いた部分でのルーパ角度偏差の平均值をコイル内ルー パ角度偏差の代表値とし, この值の統計的性質を調べた. その度数分布を Fig. 9 に示す. これより本手法の方が従 来の PI 制御よりも平均值が改善されており, 分散も小さ いことがわかる. また,このテスト中のハンチングの発

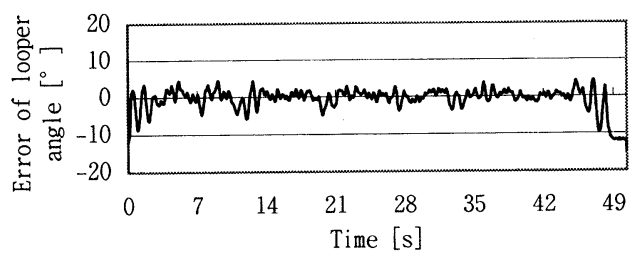

(a) Error of looper angle

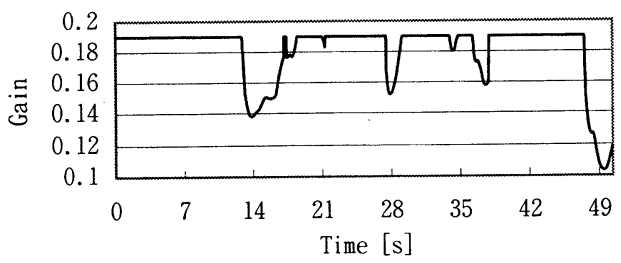

(b) Gain intervention value

Fig. 8 Test results by interpolated control $(J 1=4.0)$

生率は $0 \%$ であった。

このことは, 補間コントローラによってハンチングを 確実に抑制した結果, デフォルトしているゲインを増加 させた操業が可能となり, その結果として, 圧延材の先 後端を除いた部分のルーパ角度特性が向上したと解釈で きる。

\section{6. おわりに}

熱延仕上げミルにおけるルーパ高さ制御において, 補 間コントローラを用いた制御系を構築し，実機テストを 行った. その結果, 補間コントローラによって特性変動に 
対する適正なゲイン設定ができ，ルーパの不安定現象が

抑制されることを確認した。

本研究成果は, 現在, 実機稼働中であり継続してハン

チングを抑制している。

\section{参考文献}

1) J. C. Price: The Hot Strip Mill Looper System; IEEE Trans., Vol. IA-9, No. 5, pp. 556-562 (1973)

2) 小寺, 渡辺: 熱間圧延機ルーパにおける多变数制御の応用; 第 22 回自動制御連合講演会前刷, pp. 305-306 (1979)

3) 小林ほか：ホットストリップミル仕上圧延機におけるルーパ 非干渉制御 ; 第 27 回自動制御連合講演会前刷, pp. 347-348 (1984)

4) 中山ほか：熱延ルーパ系の完全非干渉制御；第 31 回システ 厶と制御研究発表講演会講演論文集, pp. 3-4 (1987)

5) 中川ほか：最適レギュレータによる熱延板厚・ルーパ制御；実 システムに扔ける制御理論応用シンポジューム資料, pp. 8388 (1991)

6) 福島ほか: 鋼鉄熱間仕上圧延機におけるルーパ最適多変数制 御；東芝レビュー, Vol. 42, No. 11, pp. 827-830 (1987)

7）塩谷ほか：多変数制御理論に基づく高応答ルーパ制御の開発; 新日鉄技報, No. 347 , pp. 74-77 (1992)

8) 村松, 池田, 玉井：動作状態が変化する多入出力システムの安 定化 ; システム制御情報学会論文誌, Vol. 7, No. 2, pp. 4250 (1994)

9) 村松, 池田：動作状態が変化する制御対象の安定化; 第 15 回 Dynamical System Theory シンポジウム資料, pp. 53-56 (1992)

10) 西野, 池田, 村松：動作状態が変化するプラントに対する補 間コントローラ; 第 15 回 Dynamical System Theory シ ンポジゥム資料, pp. 67-70 (1992)

11) 星井, 池田, 村松：動作状態が変化するシステムのロバスト 制御；第 37 回自動制御連合講演会前刷, pp. 55-56 (1994)

12) 村松, 池田, 星井: 動作状態が変化する制御对象の安定化; 計測自動制御学会論文集, Vol.31, No. 9, pp. 1336-1342 (1995)

13) 藤崎, 浅田, 北村: 熱延仕上げミルにおけるルーパ高さのロ バスト制御; 第 34 回システム制御情報学会研究発表講演会 講演論文集, pp. 321-322 (1990)

14) T. Tanaka, Y. Aizawa and H. Eguchi: Multiple operating conditions model and design of gain scheduler; 第 34 回自動制御連合講演会前刷, pp. 239-242 (1991)

15) 山口, 田鍋, 村上, 後藤 : ファジィ連想記憶システムを用いた 適用制御; 電気学会論文誌 $(C)$, Vol. 111, No. 1, pp. 40$46(1990)$

16) B. K. Ghosh: An approach to simultaneous system design, part2: Nonswitching gain and dynamic feedback compensation by algebraic geometric methods; SIMA J. Control and Optimization, Vol. 26, No. 4, pp. 919-963 (1988)

17) 保田: 構造的不確かさをもつシステムのロバスト安定化; 電 子情報通信学会論文誌 (A), Vol. J75-A, No. 5 pp. 926933 (1992) 